\title{
1 \\ Party rules: Promises and pitfalls
}

\author{
Marian Sawer and Anika Gauja
}

Australian politics has been synonymous with party politics for much of its history. Today the strong party identifications of the past have been breaking down and a multiplicity of minor parties and microparties has been winning seats in our parliaments, from the Australian Sex Party to the Motoring Enthusiast Party. For some commentators, this represents a welcome injection of diversity into the Australian political system. For others, however, these parties create confusion among voters and frustrate the mandates of 'democratically' elected legislators. Is this a problem and, if so, what should be done about it? What is or what should be the role of political parties in representative democracy and do we need stronger party regulation to underpin it? Why is there always a gap between what we seek from regulation and what is actually achieved?

In this introduction, we set out the main regulatory challenges concerning the place and function of political parties in Australian representative democracy. We begin by examining the constitutional recognition of political parties in a comparative context and trace the increasing international trend to legislative regulation associated with the role of political parties as 'public utilities'. We then turn to recent developments in party regulation in Australia and the existing literature, highlighting the most significant aspects of the debate over party regulation. We see this as occurring in four main areas: the provision of public funding, the regulation and restriction of private 
funding, limits on expenditure and the extent to which the law should regulate the 'internal' activities of political parties - most notably, candidate selection.

\section{Political parties and recognition of their place in democracy}

While political parties have played a central role in our political system since the late nineteenth century, legal recognition was slow to emerge. Parties were absent from the Australian Constitution, as they were from other written constitutions of the time. When the American Constitution was drafted, for example, the influence of 'faction' was seen as distorting the formation of the popular will or the disinterested judgement that legislators should bring to issues. Later, many women's suffrage activists were highly critical of the 'corrupt system of party politics', while others despaired of an 'iron law of oligarchy', which meant that imperatives of organisational survival inevitably took priority over the original goals of social democratic parties. ${ }^{1}$

After World War II, much of this original suspicion of political parties began to evaporate. In the wake of fascism and again in the Cold War context, the existence of effective party competition became central to the very definition of democracy, at least in the West. The term 'democracy' was to be reserved for political systems where a plurality of political parties was able to contest elections. The freedom to join (or form) a political party of choice became emblematic of the freedom of association.

It might seem odd, then, that political parties were not mentioned in either the Universal Declaration of Human Rights (1948) or the International Covenant on Civil and Political Rights (1966), which eventually flowed from it. This silence most likely stems from the impossibility of reaching consensus on the relationship between democracy and party pluralism at a time when there were many

1 Leading Australian suffragists like Rose Scott urged enfranchised women not to become 'camp followers to a corrupt system of party politics'. Betty Searle (1988) Silk and Calico: Class, Gender and the Vote, Sydney: Hale \& Iremonger, p. 29. The concept of the iron law of oligarchy was put forward by Robert Michels, based on observation of the German Social Democratic Party. Robert Michels (1911) Political Parties: A Sociological Study of the Oligarchical Tendencies of Modern Democracy, Leiden: Klinkhardt. 
'people's democracies' that were both one-party states and members of the United Nations (UN). ${ }^{2}$ Nonetheless, by 1996, the Human Rights Committee, the treaty body for the covenant, issued General Comment 25, which concluded that the freedom to join or form political parties was an essential adjunct to the right to participate in periodic elections, something covered by the covenant. ${ }^{3}$ In the twentyfirst century, guarantees of party pluralism have been included in a number of regional treaties and charters on democratic governance.

Ideally, in addition to being a vehicle for electoral competition, political parties also provide a meaningful space for political engagement and democratic deliberation and for policy development and agenda setting. These are all crucial democratic functions and, hence, we might expect parties to receive some recognition in democratic constitutions. However, while elections have been subject to detailed regulation, this has not generally been true of political parties until recent decades. Political parties began receiving constitutional recognition in postwar Europe, first in Iceland, Austria, Italy and Germany, but then more generally and in countries emerging from authoritarian and communist rule (see Table 1.1).

For example, in Germany, the 1949 Basic Law speaks of the role of political parties in 'the formation of the political will of the people'.

The constitutions of a number of European countries, including Germany, Spain and Portugal, go beyond recognition of the external role of political parties and also require parties to be democratic in their internal structure and operation. In Australia, however, political parties were generally regarded as private entities until the 1980s. They are still mentioned in the Australian Constitution only in relation to the filling of casual Senate vacancies (a successful amendment in 1977), rather than in relation to their broader democratic functions, in contrast with many European constitutions.

2 Gregory H. Fox (1992) ‘The Right to Political Participation in International Law', Yale Journal of International Law 17: 556-8.

3 Human Rights Committee (HRC) (1996) 'General Comment 25(57)', General Comments under article 40, paragraph 4, of the International Covenant on Civil and Political Rights, Adopted by the Committee at its 1510th meeting, UN Doc. CCPR/C/21/Rev.1/Add.7, available at: wwwl.umn. edu/humanrts/gencomm/hrcom25.htm. 
PARTY RULES?

Table 1.1 Date of first acknowledgement of political parties in national constitutions: Europe

\begin{tabular}{|l|c|}
\hline Country & Year \\
\hline Iceland & 1944 \\
\hline Austria & 1945 \\
\hline Italy & 1947 \\
\hline Germany & 1949 \\
\hline France & 1958 \\
\hline Cyprus & 1960 \\
\hline Malta & 1964 \\
\hline Sweden & 1974 \\
\hline Greece & 1975 \\
\hline Portugal & 1976 \\
\hline Spain & 1978 \\
\hline Norway & 1984 \\
\hline Hungary & 1989 \\
\hline Croatia, Serbia, Bulgaria & 1990 \\
\hline Latvia, Romania, Slovenia & 1991 \\
\hline Czech Republic, Estonia, Lithuania, Poland & 1992 \\
\hline Ukraine & 1996 \\
\hline Finland, Switzerland & 1999 \\
\hline Luxembourg & 2008 \\
\hline
\end{tabular}

Source: Party Law in Postwar Europe, available at: partylaw.leidenuniv.nl.

Nonetheless, Australia has not been immune to the global trend towards increased regulation of political parties in the late twentieth and early twenty-first centuries. As Ingrid van Biezen notes, parties have increasingly been treated as public utilities to be regulated for the achievement of public purposes rather than as private associations based on voluntary principles. ${ }^{4}$ These public purposes include legislative recruitment, electoral competition and the formation of government and opposition, as well as developing policy agendas and mobilising the vote. 
It is notable that this increased regulation and the treatment of parties as public utilities have coincided with changes in the relationship between parties and democracy throughout the world, including decreases in strong party identification and increases in non-party movements and campaigns as sites of political activity. Throughout the Western world, party membership has been dropping since at least the 1980s and, in Australia in 2006, the Australian Bureau of Statistics estimated the number of those belonging to political parties to be as low as 1 per cent of the adult population. Trust in political parties is also at an all-time low, with a recent survey showing only 3 per cent of Australian respondents had a lot of trust in political parties. $^{5}$ The general disaffection with political parties is reflected in the way those registering new ones sometimes try to avoid the word-for example, the Nick Xenophon Team, the Jacqui Lambie Network or the longer-established Australian Greens or Pauline Hanson's One Nation.

Australians are much more likely to engage in other forms of political participation such as attending a protest march, meeting or rally (5.2 per cent), signing a petition (22.5 per cent) or engaging in political consumerism (24.6 per cent). ${ }^{6}$ In 2016, the campaigning organisation GetUp! claimed membership of over 1 million-far more than all the political parties combined. ${ }^{7}$ It should be noted, however, that its definition of membership is less rigorous than that of Australian political parties, which in turn are notoriously secretive about their membership numbers.

Not only has the role of political parties as a venue for political participation been shrinking, it also has been problematised by influential strands of democratic theory: rational choice and deliberative democracy theory. Rational choice or the economic theory of democracy suggests that what is central to democracy is party competition in the electoral marketplace. Internal party democracy gets in the way of efficient competition for votes as it gives too great

5 Andrew Markus (2014) Mapping Social Cohesion: The Scanlon Foundation Surveys 2014, Melbourne: Monash University, p. 32, available at: scanlonfoundation.org.au/wp-content/ uploads/2014/10/2014-Mapping-Social-Cohesion-Report.pdf.

6 Australian Bureau of Statistics (ABS) (2007) General Social Survey: Summary Results Australia 2006, ABS Cat. No. 4159.0, Canberra: ABS. In contrast with the 2006 party membership figure, in the 1960s some 4 per cent of the adult population were estimated to be party members.

7 See getup.org.au/about. 
a role to party members in the selection of candidates and development of policy. ${ }^{8}$ As part of the case for the 'inefficiency' of internal party democracy, it is also suggested that the preferences of party activists are likely to be more 'extreme' than those of party voters. ${ }^{9}$

In contrast, deliberative democracy theorists argue that it is the quality of public debate rather than the efficiency of party competition that is the central democratic value. They argue that political parties may detract from rather than contribute to deliberative quality, which includes respectful consideration of evidence and argument and a consequent readiness to change position. This quality may be absent from the way in which parties contribute to parliamentary debate, which may be highly adversarial and disrespectful. It may also be absent from the way in which policy is made inside parties, which may marginalise party members and owe more to leadership decisions informed by non-deliberative market research. While advocates of deliberative democracy often seem to give up on political parties or parliaments as venues for democratic deliberation, it has been argued that political parties could beneficially conduct internal deliberative polls when developing party manifestos. ${ }^{10}$

\section{Expanding party regulation: Public funding and candidate selection}

Regardless of these competing democratic arguments, if parties are becoming less central to the political life of ordinary citizens, why has this coincided with their increased regulation? Some would argue that this is not a coincidence. ${ }^{11}$ Political parties have falling memberships but election campaigning has become increasingly expensive, particularly when it involves paid advertising in the electronic media. In many democracies, political parties now receive public subsidies to assist them in their campaigning and this funding requires regulation.

\footnotetext{
8 Joseph Schumpeter (1943) Capitalism, Socialism and Democracy, London: Allen \& Unwin. 9 John May (1973) 'Opinion Structure of Political Parties: The Special Law of Curvilinearity', Political Studies 21: 135-51.

10 Jan Teorell (1999) 'A Deliberative Defence of Intra-party Democracy', Party Politics 5 (3): 373. 11 Richard Katz and Peter Mair (1995) 'Changing Models of Party Organization and Party Democracy: The Emergence of the Cartel Party', Party Politics 1(1): 5-28; Ingrid van Biezen and Peter Kopecky (2007) 'The State and the Parties: Public Funding, Public Regulation and Rentseeking in Contemporary Democracies', Party Politics 13(2): 235-54.
} 
While such public funding is a relatively recent phenomenon, beginning with countries such as Costa Rica, Uruguay and Germany in the 1950s, today public funding exists in three-quarters of liberal democracies. ${ }^{12}$ Public funding is seen as important in enabling political pluralism, on the one hand, and in shielding parties from private interests, on the other; so important that it is now enshrined in the constitutions of a number of developing democracies. It also reflects the understanding that while many people now prefer to engage in political activity outside the party system, political parties are still central to the operation of representative democracy.

Public funding is usually distributed by criteria such as votes at the previous election or, for new parties, community support reflected in opinion polls or the size of party membership. It is intended to ensure that all parties have the means to communicate their message, regardless of how deep the pockets of their supporters are. A less sympathetic viewpoint would be that incumbent political parties shore up their advantage through the appropriation of state resources of various kinds, even including, in Australia, the use of parliamentary allowances for party databases, including annual amounts for software and training. For some, the rent-seeking relationship of political parties with the state is of greater concern than the reliance of political parties on private money, although both might be detrimental to the public good. There is now a large literature developing the concept of the 'cartel party' - addressed by several authors in this book - which compensates for a declining membership by drawing increasingly on state resources, in collusion with other parties that form part of the cartel. ${ }^{13}$ Others have contested the explanatory power of the cartel thesis, at least in relation to Australia, suggesting that the major parties simply act as rational utility maximisers rather than actively colluding against those outside the cartel. ${ }^{14}$

With public funding comes increased regulation of political finance, intended to make more transparent or decrease reliance on private sources of funding and to ensure a more level playing field for electoral competition. As Graeme Orr nicely puts it in this volume,

12 Van Biezen and Kopecky, 'The State and the Parties'.

13 See Richard Katz and Peter Mair (2009) 'The Cartel Party Thesis: A Restatement', Perspectives on Politics 7(4): 753-66.

14 Murray Goot (2006) 'The Party System, One Nation and the Cartelisation Thesis', in Ian Marsh (ed.) Political Parties in Transition?, Sydney: The Federation Press. 
the three rationales of public funding and political finance regulation are: 'resourcing parties, dampening demand for private money and political equality'. Concern over the playing field for electoral competition also leads to the introduction of party registration, linked to access to the ballot paper. The requirements for party registration (for example, number of members, number of candidates being fielded, ability to pay the registration fee) can effectively control the number of political parties able to contest elections. While political scientists have often explored the relationship between the nature of the electoral system and the nature of the party system (majoritarian systems encouraging two-party systems; proportional representation encouraging multiparty systems), less attention has been given to the effects of party regulation on party systems. One recent exception has looked at the relationship between the nature of party regulation, party formation costs and the number of political parties in Latin America. ${ }^{15}$

As pointed out by Graeme Orr, party registration is not the only limitation on access to the ballot paper; there are also candidate deposits, which may add up to a large amount if the party is running in all seats. ${ }^{16}$ They are, however, refundable if the candidate wins more than a certain proportion of the vote - usually 4 per cent in Australia. The combined effects of party registration requirements and nomination deposits may ensure that the ballot paper is not so crowded as to preclude informed and effective choice by voters, but it may also suit the interests of established parties in discouraging challengers.

As political parties are the gatekeepers of political office, the way they select their candidates and leaders has become an issue of public interest. There has been much public dissatisfaction expressed over the fact that a prime minister can be overthrown through a 'palace coup' in his/her parliamentary party without reference to a broader constituency such as the party membership. This has led to reforms in how party leaders

15 Gerardo Scherlis (2014) 'Political Legitimacy, Fragmentation and the Rise of Party-formation Costs in Contemporary Latin America', International Political Science Review 35(3): 307-23.

16 Graeme Orr (2015) 'The Law Governing Australian Political Parties: Regulating the Golems?', in Narelle Miragliotta, Anika Gauja and Rodney Smith (eds) Contemporary Australian Political Party Organisations, Melbourne: Monash University Publishing. 
are selected in a number of countries. ${ }^{17}$ Increasingly, as the practices of political parties become subject to judicial review, there is a concern that the internal processes of parties should themselves be democratic and that rules be applied fairly and openly.

Another development has been the perception since at least the 1990s that the under-representation of women in legislatures constitutes a democratic deficit. This understanding of political equality has been reinforced by interpretation of the UN Convention on the Elimination of All Forms of Discrimination against Women (CEDAW) and by the Beijing Platform for Action, as well as by the many international organisations providing democracy assistance and assessment. Since political parties are recognised to be the gatekeepers of legislative recruitment, commitments to increase the legislative representation of women (and, in some cases, of ethnic minorities) have brought in their train increased regulation of candidate selection by parties. Since 1991, when Argentina led the way with legislation for electoral gender quotas, some 60 countries have followed suit, including most recently Greece and Ireland. ${ }^{18}$ Globally, some 28 countries also have ethnic quotas for elections for their national parliament, which can involve mechanisms such as special districts as well as requiring ethnic quotas to be applied to party lists or reserving seats for ethnic parties. ${ }^{19}$ Sanctions applied to political parties for failing to meet the quota may include rejection of the party list or loss of election funding. The introduction of quotas has proved more difficult in countries with single-member electoral systems, where quotas may appear to strengthen the hand of party leaders at the expense of local democracy in parties.

While political science has been enriched by classic studies of political parties for more than a century, party regulation is a much more recent subject of inquiry. It is, however, now attracting the attention of political scientists. They have created cross-national databases on

17 William P. Cross and André Blais (2012) Politics at the Centre: The Selection and Removal of Party Leaders in the Anglo Parliamentary Democracies, Oxford: Oxford University Press.

18 Another 34 countries have reserved seats and, in an additional 37 countries, at least one parliamentary party has a candidate quota in its rules. See International Institute for Democracy and Electoral Assistance (International IDEA) (2013) Atlas of Electoral Gender Quotas, Stockholm: International IDEA.

19 Karen Bird (2014) 'Ethnic Quotas and Ethnic Representation Worldwide', International Political Science Review 35 (1): 12-26. 
party regulation as well as studies of its character and consequences for the nature of party competition, political legitimacy and parties' relationship with the state. ${ }^{20}$ Working with the International Institute for Democracy and Electoral Assistance (IDEA), political scientists have also created a database on electoral quotas worldwide (quotaproject.org), showing whether these are legislated or simply adopted into party rules. A new political science literature examines the effectiveness of different types of quota regulation in ensuring political parties become a more inclusive source of legislative recruitment, whether this involves gender or ethnic quotas. ${ }^{21}$ In addition to the massive literature on electoral quotas, there is also an emerging interest in other aspects of party regulation and how it can be used to promote gender equity and inclusiveness. ${ }^{22}$ For example, public funding of parties may include fiscal incentives for the promotion of gender equality within the party organisation. In Finland, 12 per cent of the annual subsidy provided to parliamentary parties must be used to fund their women's wings. ${ }^{23}$ This interest in party regulation to promote gender equality extends beyond formal regulation to the realm of 'soft regulation'.

In general, 'soft regulation' or standard setting is an increasingly significant aspect of any form of regulation and complements more 'traditional' sources such as constitutions and legislative instruments. ${ }^{24}$

20 Ingrid van Biezen (2012) 'State Intervention in Party Politics: The Public Funding and Regulation of Political Parties', in Keith Ewing, Jacob Rowbottom and Joo-Cheong Tham (eds) The Funding of Political Parties: Where Now?, Abingdon: Routledge; Ekaterina Rashkova and Ingrid van Biezen (eds) (2014) 'A Contested Legitimacy: The Paradoxes of Legal Regulation of Political Parties, International Political Science Review 35(3)(Special Issue).

21 For important examples of the quota literature, see Mona Lena Krook (2009) Quotas for Women in Politics: Gender and Candidate Selection Reform Worldwide, New York: Oxford University Press; Susan Franceschet, Mona Lena Krook and Jennifer Piscopo (eds) (2012) The Impact of Gender Quotas, New York: Oxford University Press; Mona Lena Krook and Pär Zetterberg (eds) (2014) 'Electoral Quotas and Political Representation: Comparative Perspectives', International Political Science Review 35(1)(Special Issue).

22 Sarah Childs (2013) 'In the Absence of Electoral Sex Quotas: Regulating Political Parties for Women's Representation', Representation 49(4): 401-23.

23 Mona Lena Krook and Pippa Norris (2014) ‘Beyond Quotas: Strategies to Promote Gender Equality in Elected Office', Political Studies 62: 16, doi:10.1111/1467-9248.12116; Julie Ballington and Muriel Kahane (2014) 'Women in Politics: Financing for Gender Equality', in Funding of Political Parties and Election Campaigns: A Handbook on Political Finance, Stockholm: International IDEA, available at: idea.int/publications/.

24 See Orly Lobel (2004) 'The Renew Deal: The Fall of Regulation and the Rise of Governance in Contemporary Legal Thought', Minnesota Law Review 89: 343-470; Bengt Jacobsson and Kerstin Sahlin-Andersson (2006) 'Dynamics of Soft Regulation', in Marie Laure Djelic and Kerstin Sahlin-Andersson (eds) Transnational Governance: Institutional Dynamics of Regulation, New York: Cambridge University Press. 
While soft regulation can take place at all levels of governance, particularly in relation to environmental issues, the issuing of standards of democratic performance takes place primarily at the international and regional levels. Such soft regulation encompasses the norm-generating activities of transnational bodies, including the international standards, codes of conduct, handbooks and guidelines they produce and disseminate. It does not involve the direct use of sanctions on the part of the norm-generating body. However, it has been described as 'inquisitive regulation', because member states are often required to report to or 'open up' to others so they can examine and critically judge what they are doing. ${ }^{25}$ Peer pressure is generated through rankings that are regularly produced and released to the media and through sharing of best practice. Such rankings may also be of considerable interest to international donors.

There are many examples of international bodies developing standards and rankings relating to different areas of democratic governance and election management, including Transparency International, the Inter-Parliamentary Union and the International Foundation for Electoral Systems (IFES). For a good example of such soft regulation in the area of party regulation see the Guidelines on Political Party Regulation drawn up by the Venice Commission of the Council of Europe and the Office for Democratic Institutions and Human Rights of the Organization for Security and Co-operation in Europe (OSCE). The 10 underlying principles set out in these guidelines include equal treatment, meaning that party regulation should treat all parties equally and prevent incumbent political parties or candidates from using state resources to obtain unfair advantage. Equal treatment also covers temporary special measures for women and members of minorities subject to past discrimination. ${ }^{26}$

Other international bodies providing support for democracy building also include elements in their standard-setting to promote gender equality. For example, the guidelines on party finance drawn up by the International IDEA include recommendations to close the gender funding gap in elections through conditional public funding, while

25 Bengt Jacobsson (2006) 'Regulated Regulators: Global Trends of State Transformation', in Djelic and Sahlin-Andersson, Transnational Governance, p. 207.

26 Organization for Security and Co-operation in Europe (OSCE) (2011) Guidelines on Political Party Regulation, Warsaw: OSCE Office for Democracy and Human Rights, available at: osce.org/ odihr/77812? download=true. 
the Organisation for Economic Co-operation and Development (OECD) also cites as good practice that public funding of political parties be conditional on gender ratios. ${ }^{27}$ In addition to the international bodies concerned with democratic governance, the international associations of political parties may also engage in soft regulation and the promotion of gender equality norms. For example, the Socialist International, which brings together some 150 social-democratic, socialist and labour parties, has helped promote the use of electoral gender quotas; the adoption of these in party rules is one of the factors taken into consideration when new parties apply to join. Soft regulation is not as highly developed in the field of party regulation, however, as it is in the field of electoral governance.

\section{Party regulation in Australia}

As noted above, the first and only reference to political parties in the Australian Constitution - which requires the filling of casual Senate vacancies by a representative of the same party - was inserted in 1977. Although the Labor Party was emerging as Australia's first 'mass' political party in the 1890s, at the time of the Constitutional Conventions, there was (and still is) no mention of the democratic functions of political parties. This silence over the role of political parties in representative democracy is also true of Australia's State constitutions; in 2000, the Queensland Constitutional Review Commission felt the issue of constitutional recognition of political parties was one 'whose time has not yet come in Australia'. ${ }^{28}$

While the time for constitutional recognition has not yet come in Australia, the statutory recognition of political parties was also very slow in coming. A pioneering 1914 analysis of Australian political systems noted the way in which the political centre of gravity was

27 Organisation for Economic Co-operation and Development (OECD) (2016) 2015 Recommendation of the Council on Gender Equality in Public Life, Paris: OECD, available at: oecd.org/gov/2015-oecd-recommendation-of-the-council-on-gender-equality-in-public-life9789264252820-en.htm.

28 Constitutional Review Commission's 2000 Issues Paper, quoted in Scott Bennett (2002) Australia's Political Parties: More Regulation?, Parliamentary Library Research Paper 21, Canberra: Parliament of Australia. 
moving from parliament to parties but proved completely faulty in its prediction that regulation could be expected to follow 'at any rate so as to regulate the process of selecting candidates' ${ }^{29}$

In the 1970s, there was still considerable resistance even to statutory recognition of political parties, let alone regulation of internal processes. The efforts of the Whitlam Government to legislate for party names to appear on ballot papers were rejected in the Senate, leaving it up to the Tasmanian Labor Government to become the first to introduce party registration. ${ }^{30}$ Systems of party registration were finally introduced in most jurisdictions in the 1980s, although Queensland and Western Australia waited until 1992 and 2000, respectively, and the Northern Territory until 2004 (see Table 1.2).

While generally the introduction of party registration meant the appearance of party names on ballot papers, this was not the case in New South Wales (NSW). The anomaly occurred because the State Labor Government introduced party registration for the purpose of public funding through a separate Act, with an authority separate from the NSW Electoral Commission. So although parties were registered in NSW from 1981 for the purpose of public funding, their names did not appear on ballot papers even after parties were allowed to lodge group tickets for the Legislative Council. It was not until 1991 that NSW voters were finally allowed to see the party affiliations of the candidates on their ballot papers. Even then it was only because the Australian Democrats held the balance of power in the Legislative Council and the government needed their support for a planned redistribution. ${ }^{31}$ While the Australian Democrats were generally at the forefront of electoral reform, small parties with relatively few people to hand out how-to-vote cards outside the polling place also had a natural interest in getting their party's name on to the ballot paper.

29 W. Harrison Moore (1914) 'Political Systems of Australia', in G. H. Knibbs (ed.) Federal Handbook, [prepared in connection with the 84th meeting of the British Association for the Advancement of Science, Australia, August 2014], Melbourne: Government Printer, p. 564.

30 At first, the party registration requirements in Tasmania were only a slight expansion of the previous requirements for candidate nominations, requiring statutory declarations from seven members for a party to be registered (Part viiia, 1974 Tasmanian Electoral Act). Nonetheless, party names did appear on Tasmanian ballot papers in the 1976 and 1979 State elections, contrary to accepted wisdom that they first appeared on Commonwealth ballot papers.

31 Antony Green (2001) 'The 1991 Election', in Michael Hogan and David Clune (eds) The People's Choice: Electoral Politics in 20th Century NSW. Volume 3, Sydney: Parliament of New South Wales and University of Sydney, p. 316. Party registration was transferred from the Election Funding, Expenditure and Disclosures Act to the Parliamentary Electorates and Elections Act ahead of the 1991 election (information from Antony Green, 22 March 2016). 
PARTY RULES?

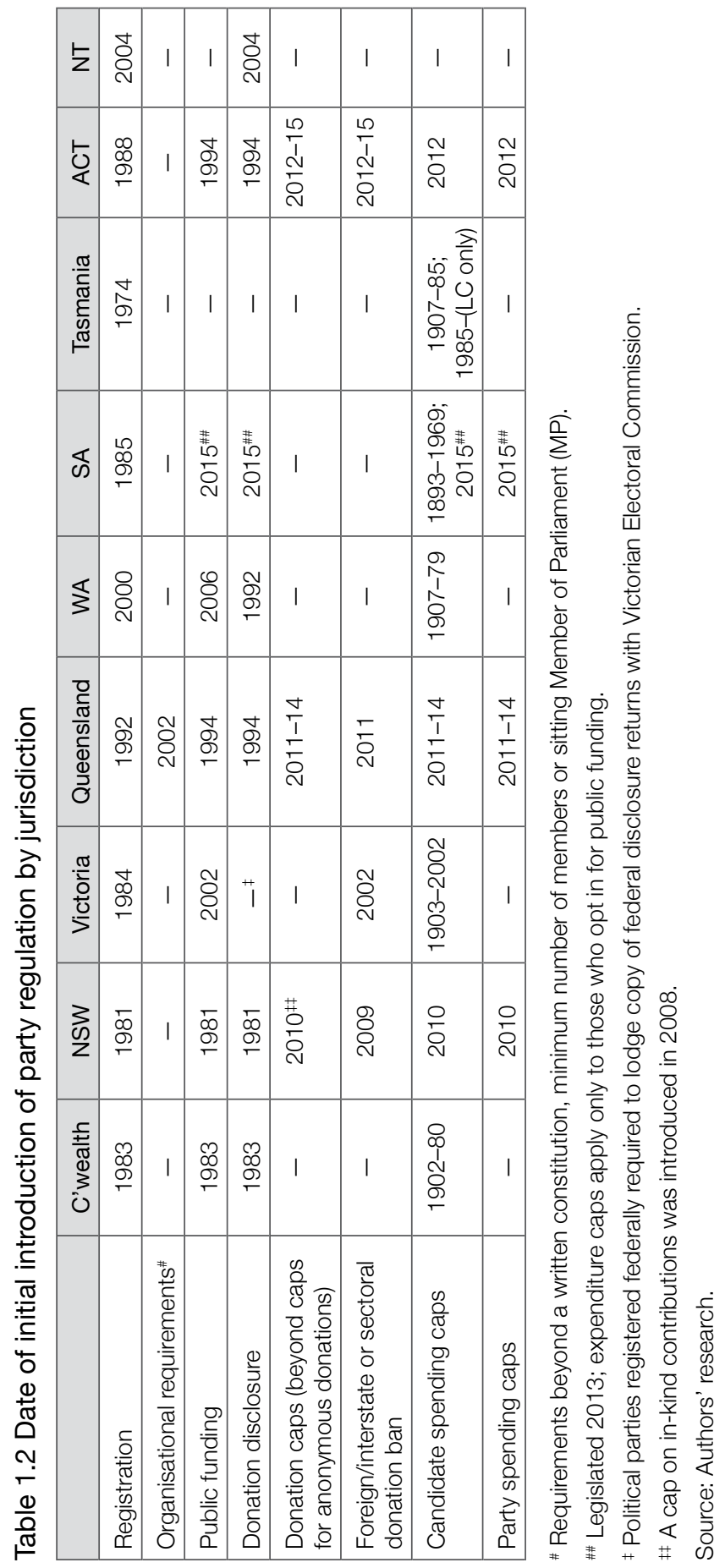


All jurisdictions now require the registration of party names and abbreviations for ballot-labelling purposes, and the registration of party emblems has been introduced in 2016 under changes to the Commonwealth Electoral Act. ${ }^{32}$ The growth of party regulation was sometimes controversial and was opposed in principle by the conservative parties (see Sarah John, this volume).

The first book on Australian electoral and party regulation did not appear until some 50 years after the first books on the party system. ${ }^{33}$ This delayed scholarly interest to some extent reflects the delayed transition of Australian political parties from organisations regarded as essentially private and beyond the purview of the law to organisations from which public accountability was demanded. During this period, scholarship on regulation was blossoming, but regulatory theory was yet to be applied to the regulation of political parties. ${ }^{34}$

This began to change with a major Australian project on electoral and party regulation. Graeme Orr, Bryan Mercurio and George Williams brought together political scientists and legal scholars as well as electoral administrators to work on this project and received funding from both the Australian Research Council (ARC) and the Electoral Council of Australia, the body that represents Commonwealth, State and Territory electoral commissions. This tradition of bringing together different disciplines and linking scholars and practitioners has continued under the auspices of both the Democratic Audit of Australia and the Electoral Regulation and Research Network, and is maintained in the current volume. Research has been published on the impact and politics of electoral and party laws ${ }^{35}$ and, in particular, the

32 After the 2013 federal election, in which the Liberal Democratic Party won a Senate seat in NSW, the Liberal Party of Australia recommended that party symbols be included on the ballot paper to reduce potential confusion caused by similar party names.

33 Louise Overacker (1952) The Australian Party System, New Haven, Conn.: Yale University Press; James Jupp (1964) Australian Party Politics, Melbourne: Melbourne University Press. Then, some 50 years later, Graeme Orr, Bryan Mercurio and George Williams (eds) (2003) Realising Democracy: Electoral Law in Australia, Sydney: The Federation Press. Two years earlier some material on partisanship and party regulation had appeared in a collection on Australian innovations in electoral governance: Marian Sawer (ed.) (2001) Elections Full, Free and Fair, Sydney: The Federation Press.

34 The development of the massive interdisciplinary research program on regulation (RegNet) housed at The Australian National University is best described in Peter Drahos (ed.) (forthcoming) Regulatory Theory: Foundations and Applications, Canberra: ANU Press.

35 See, for example, Anika Gauja (2010) Political Parties and Elections: Legislating for Representative Democracy, Farnham: Ashgate; Graeme Orr (2010) The Law of Politics: Elections, Parties and Money in Australia, Sydney: The Federation Press. 
vexed issue of campaign finance regulation. ${ }^{36}$ These studies have been complemented by assessments of how well party law and electoral legislation serve Australian democracy, ${ }^{37}$ and to what extent they meet international standards of good practice. ${ }^{38}$ A central problem in achieving the latter aim is that regulatory reform is dependent on parties in government, which are likely to be more concerned with their own interests than with international best practice. As Anika Gauja argues in this volume, courts have often stepped in to enforce democratic freedoms and protect the rights of party members where legislators are reluctant to do so.

Australia has a long tradition of innovation in the area of electoral administration, but also a tradition of partisan distrust of proposals for change. Since 2013, there has been a plethora of activity at both federal and State levels, and there is more to come. The 2013 federal election provided a vivid example of the unintended consequences for the party system of a previous electoral reform, paving the way for further reforms. In 1983 the single transferable vote (STV) system for the Senate was reformed to minimise the informal vote resulting from the requirement for voters to mark preferences for all candidates on the ballot paper. Instead, voters were now given the choice either to mark their preferences for all candidates 'below the line' or to vote for just one party 'above the line' and have preferences distributed in accordance with registered tickets. Most voters chose the easier abovethe-line option; its flaws became highly visible only when, for tactical reasons, parties began distributing preferences to unlike rather than like parties, in ways disapproved of by their voters. ${ }^{39}$

In 2013 there was a surge in the number of parties contesting the election, with 54 different parties registered (see Norm Kelly, this volume). There were so many party and candidate names that font

\footnotetext{
36 See, for example, Sally Young and Joo-Cheong Tham (2006) Political Finance in Australia: A Skewed and Secret System, Report No. 7, Melbourne: Democratic Audit of Australia, available at: apo.org.au/research/political-finance-australia-skewed-and-secret-system-0; Joo-Cheong Tham (2010) Money and Politics: The Democracy We Can't Afford, Sydney: UNSW Press.

37 Marian Sawer, Norman Abjorensen and Phil Larkin (2009) Australia: The State of Democracy, Sydney: The Federation Press.

38 Norm Kelly (2012) Directions in Australian Electoral Reform: Professionalism and Partisanship in Electoral Management, Canberra: ANU E Press, available at: press.anu.edu.au/titles/directionsin-australian-electoral-reform/.

39 Marian Sawer (2005) 'Above-the-Line Voting in Australia: How Democratic?', Representation 41(4): 286-90.
} 
sizes on Senate ballot papers had to be reduced (to 7.6 points in NSW) and voters in the larger States had to be issued with plastic magnifying sheets with which to read them. Most of these new parties had little community support but had names designed to attract some groups of voters, such as the Smokers Rights Party. Some of these microparties, which crowded the Senate ballot papers for the different States and Territories, were successful in gaining Senate seats thanks to elaborate arrangements for 'preference harvesting', which had been pioneered at the State level. A Victorian candidate of the Motoring Enthusiast Party gained election to the Senate with only 0.5 per cent of firstpreference votes, building a quota (14.3 per cent) through deals that gave him preferences from the group voting tickets (GVTs) registered by 23 other parties. Only 3.5 per cent of the votes that elected him were votes for his own party, with the rest coming via the voting tickets of unrelated parties, ranging from the Shooters and Fishers to the Animal Justice Party.

This kind of outcome prompted much adverse comment, and the major parties were particularly critical of the existing regulation that had allowed this proliferation of parties. The regular inquiry into the conduct of the federal election by the Joint Standing Committee on Electoral Matters (JSCEM) recommended that the number of members needed to register a party be increased and that the system of GVTs registered by parties be replaced with an optional preferential system whereby voters could express their preference for one or more parties above the line or for a minimum number of candidates below the line. While these recommendations would clearly reduce the number of parties contesting federal elections, they were justified in terms of the need to redress a system where 'electors felt their votes had been devalued by preference deals and that they had been disenfranchised by being forced to prefer unpreferred candidates' ${ }^{40}$ In the event, group tickets were abolished and voters were instead given the option of listing their own six preferences for parties above the line or for 12 candidates below the line. ${ }^{41}$ Nothing was done to tighten up the requirements for party registration and individual parliamentarians could still register a party without any membership

40 Joint Standing Committee on Electoral Matters (JSCEM) (2014) Interim Report on the Inquiry into the Conduct of the 2013 Federal Election: Senate Voting Practices, Canberra: Parliament of Australia, p. 2.

41 Commonwealth Electoral Amendment Act 2016. 
requirement. Others continued to register microparties for advocacy purposes, including the Australian Equality Party (Marriage), the Renewable Energy Party and The Arts Party, needing only to satisfy the requirement for 500 members and a written constitution (and the $\$ 500$ registration fee).

It should be noted that the proliferation of political parties is an international phenomenon. While lax requirements for party registration are a contributing factor, another is that social media has made party formation much less labour intensive:

In Spain over 400 parties have been created since 2010. Parties are proliferating. Why? Largely because social media have made it so much easier, less time consuming and less expensive to create them. ${ }^{42}$

Those signing an electronic petition, for example, can be signed up to a related party and this is a common way to build party membership lists.

At the State level, some recent regulatory reforms have had a much shorter lifespan than the Senate GVTs. This is particularly evident in the area of political finance, where partisan differences may mean that reforms enacted by a government of one political persuasion will be changed or undone by a subsequent government. This has recently occurred following the change of government in NSW (2011) and Queensland (2012), while in the Australian Capital Territory (ACT), with a change of heart rather than a change of government, a minority Labor government undid the cap on donations introduced by a previous minority Labor government.

\section{Important debates in Australian party regulation}

In general terms, the debate surrounding the legal regulation of political parties has focused on two main areas: political finance and matters of party organisation, such as candidate selection. Political finance in turn involves two interrelated, but distinct, elements: the private funding of political parties and the provision of state

42 Simon Tormey (2015) The End of Representative Politics, Cambridge: Polity, p. 101. 
resources. Each of these elements encompasses a range of regulatory and public policy responses, such as disclosure regimes, restrictions on donations and expenditure and the provision of direct and indirect public subsidies (election funding, tax breaks, free broadcasting time, parliamentary resources and funding of party think tanks or policy development), and sits within a broader debate about the regulation of political finance more generally - including the regulation of lobbying and government advertising. As political parties receive public money and are seen to perform public functions (see the discussion of parties as 'public utilities' earlier in this chapter), regulatory responses creep into the party organisation, touching on functions such as candidate selection.

\section{The public funding of political parties}

To begin with the provision of state resources to political parties: in general, there is a hierarchy of enjoyment of such resources. Incumbent governments may benefit from the use of government advertising for partisan purposes and from strategic distribution of discretionary grants programs ('pork-barrelling'), while all incumbent parliamentarians benefit from resources such as electorate staff ${ }^{43}$ and parliamentary allowances (see Yvonne Murphy, this volume). Supposedly, such staff and allowances are provided for parliamentary and electorate purposes, with any other effects, such as promoting the re-election of the parliamentarian, only incidental. However, the use of allowances for electoral campaigning purposes has been normalised and has long been recognised as unfairly advantaging incumbents. ${ }^{44}$ In 2010 an independent review of parliamentary entitlements, appointed by the Rudd Government, recommended that access to printing and communications entitlements be removed from the date of the announcement of a federal election, along with travelling allowance for parliamentary staff working at party campaign headquarters. The review committee noted the latter created the 'not unreasonable perception that staff were engaged in party political

43 In the Federal Parliament, under the Members of Parliament (Staff) Act 1984, both Senators and Members of the House of Representatives are provided with four full-time electorate officer positions, supposedly to help them carry out their parliamentary and electorate responsibilities but not party work.

44 Nicole Bolleyer and Anika Gauja (2015) 'The Limits of Regulation: Indirect Party Access to State Resources in Australia and the United Kingdom', Governance: An International Journal of Policy, Administration and Institutions 28(3): 321-40. 
business at public expense'. An Australian National Audit Office (ANAO) report noted that as of May 2015 no progress had been made in implementing these recommendations. ${ }^{45}$

Because the use of such parliamentary resources for partisan purposes has been normalised, only the most egregious cases receive media headlines. One such case was the expenses claim lodged by the Speaker of the House of Representatives for hiring a helicopter, supposedly for official purposes, but in fact to make a spectacular entrance at a party fundraiser. ${ }^{46}$ The helicopter scandal (known colloquially as 'Choppergate') prompted another review of the parliamentary entitlements system. This was more circumspect than the unimplemented 2010 review, recommending that the more publicly acceptable term 'work expenses' be used instead of 'entitlements', but that 'electioneering' should not be explicitly excluded from the definition of 'parliamentary business'. As the review noted, this differed from the practice in New Zealand and other comparable countries, which do not allow parliamentary allowances to be used for electioneering. ${ }^{47}$

In another development, party policy launches are now often delayed because of the convention that parliamentary allowances can continue to cover travel costs and staff overtime until the campaign launch. Because of the introduction of pre-poll voting, this means that voting can begin before the party's election manifesto has been released; access to campaign resources is clearly being prioritised here over the timeliness of the formal policy launch. Candidates of parties not represented in parliament have the least access to public resources. They may be entitled to some free broadcast time on Australian Broadcasting Corporation $(\mathrm{ABC})$ and Special Broadcasting Service

45 See Recommendations 14, 15 and 16 of the Committee for the Review of Parliamentary Entitlements (2010) Review of Parliamentary Entitlements Committee Report, Canberra: Department of Finance, available at: finance.gov.au/publications/review-of-parliamentary-entitlementscommittee-report/; Australian National Audit Office (ANAO) (2014-15) Administration of Travel Entitlements Provided to Parliamentarians, ANAO Report No. 42, Canberra: ANAO, available at: anao.gov.au/ /media/Files/Audit\%20Reports/2014\%202015/Report\%2042/AuditReport_20142015_42.pdf.

46 Paul Osborne (2015) 'Speaker Bronwyn Bishop Charters Chopper for Liberal Event', Sydney Morning Herald, 15 July, available at: smh.com.au/federal-politics/political-news/speakerbronwyn-bishop-charters-chopper-for-liberal-event-20150715-gid93n.html.

47 John Conde and David Tune (2016) An Independent Parliamentary Entitlements System: Review, Canberra: Department of Finance, pp. 58-60, available at: finance.gov.au/sites/default/ files/independent-parliamentary-entitlements-system-review-feb-2016.pdf. 
(SBS) radio and television, depending on the number of seats they are contesting and their level of demonstrated public support. After the election, they will be eligible for public funding providing a threshold level of electoral support has been achieved-usually 4 per cent of the vote.

In Australia, as elsewhere, major parties may behave in a cartel-like fashion to deny public resources to minor parties or Independents (see Graeme Orr and Jennifer Rayner, this volume). One interesting example is the exclusion of minor parties from televised leaders' debates during election campaigns. Minor parliamentary parties such as The Greens (or indeed The Nationals) are routinely excluded from such leaders' debates in Australia, unlike in comparable democracies such as the United Kingdom and Canada, and the matter has not been taken to court as it has in New Zealand.

On the other hand, minor parties holding the balance of power have been able to ensure that they share in some of the resources and funding programs introduced to benefit the major parties. One example is the allocation of parliamentary party status and the additional resources and staffing that flow from such status, which is separate from the resources provided to government and the official opposition. Since the 1980s, there has been a threshold of five members or Senators for recognition as a parliamentary party in the Federal Parliament, and there are similar thresholds in other parliaments. At the federal level, The Greens have enjoyed parliamentary party status since 2007. Flowing from this status, The Greens' leader in the Senate has a range of entitlements including, in 2015, some charter air transport and 13 additional staff members above the normal entitlement to electorate staff.

There is as yet no formal regulation in any of the Australian jurisdictions regarding parliamentary party status, which by no means flows automatically from party registration for electoral purposes. So far, minor parties holding the balance of power (or serving as a coalition partner) have been the ones that have helped determine the minimum number of seats required for eligibility. ${ }^{48}$ Minor parties and Independents have also helped ensure additional staff for

48 Norm Kelly (2004) Determining Parliamentary Parties: A Real Status Symbol, Democratic Audit of Australia Discussion Paper, December, Melbourne: Australian Policy Online, available at: apo.org.au/files/Resource/kellypaper.pdf. 
crossbenchers who do not satisfy these requirements. The argument is that additional personal staff are required in the absence of the resources flowing from parliamentary party status (although another way to provide assistance with parliamentary functions such as legislative review would be to ensure adequate resources for the parliamentary library and research service). ${ }^{49}$

Although the rationale for the additional resources may be the need for Independents or parties with only one or two members to cover all portfolio areas, the resources provided are more closely tied to balance-of-power status. For example, when four Independents and the sole Greens member of the House of Representatives held the balance of power after the 2010 federal election, they were allocated two additional staff each, whereas Senator Xenophon (Independent) and Senator Madigan (Democratic Labour Party) were allocated only one additional staff member. After the 2013 federal election, this differential allocation between House of Representatives and Senate crossbenchers was reversed. Independents and members of minor parties in the House of Representatives no longer held the balance of power and their additional staff entitlement was reduced to one. On the other hand, the eight minor party and Independent Senators holding the balance of power from 2014 were allocated two additional staff. In 2016, thanks to the government having only a majority of one, Independents and minor party representatives in the House of Representatives regained a potential balance of power role. As a result, their additional staff entitlements were lifted to three, in line with an increase for the crossbench Senators (see Table 1.3). Questions about the regulation or otherwise of parliamentary party status are explored in this volume by Yvonne Murphy.

Table 1.3 Additional resources allocated for minor parties* and Independents in the federal parliament

\begin{tabular}{|l|l|l|}
\hline & House of Representatives & Senate \\
\hline 2010 & 2 additional staff & 1 additional staff \\
\hline 2013 & 1 additional staff & 2 additional staff \\
\hline 2016 & 3 additional staff & 3 additional staff \\
\hline
\end{tabular}

* Parties falling below the threshold for parliamentary party status (five members).

49 Sawer et al., Australia, p. 131. 
Other examples of minor parties joining the cartel include the funding of party think tanks through grants-in-aid administered by the Finance portfolio: first the Australian Democrats and then The Greens succeeded in joining this funding stream. Today the Labor and Liberal parties receive almost $\$ 250,000$ each year for the Chifley and Menzies research centres, respectively, while The Nationals and The Greens receive around $\$ 90,000$ each for the Page Research Centre and the Green Institute, respectively. All the think tanks (apart from the Page Research Centre) disclose their grants-in-aid funding on their websites and their deductible gift recipient status is also declared, which makes gifts to the party think tanks tax deductible.

Another example of a funding stream that a minor party sharing the balance of power has been able to join is the Australian Political Parties for Democracy Program (APPDP), introduced by the Howard Government. This provides $\$ 1$ million each to the Liberal and Labor parties every year and, since 2011, has also provided $\$ 200,000$ a year to The Greens. This particular program has received headlines from time to time, which may be worth exploring from the point of view of how cartel-like behaviour contributes to the general image of politicians and political parties 'rorting the system'.$^{50}$

The APPDP has the objective of 'strengthening democracy internationally', but only 50 per cent of the funds need to be spent in developing democracies; the rest can be spent on other kinds of international activities. In 2009 the program was subject to an adverse ANAO report that found insufficient accountability in its administration by the Department of Finance, with no requirement that the money be spent on the purposes outlined in funding applications. While, as mentioned, only 50 per cent of the funds are required to be spent as overseas development assistance, the ANAO findings still raised significant questions: only 44 per cent of the funds had been spent on countries targeted for development assistance, while 36 per cent had been spent on activities in countries such as the United

50 'Rorting the system' is an Australasian expression particularly applied to the misappropriation of public resources. 
Kingdom and the United States or on non-country-specific activities, and 20 per cent had gone to administrative costs and subscriptions to international organisations. ${ }^{51}$

As a result of the damning ANAO report, the program was shifted to the then Australian Agency for International Development (AusAID) in 2009. This shift resulted in more adverse attention when it was noticed in the Australian Electoral Commission's disclosure returns from political parties that money was being spent out of the aid budget to pay party officials to travel business class to meetings of fraternal political parties, particularly in North America and Europe, or to meetings of their corresponding international bodies such as the Socialist International or the International Democratic Union (IDU). The IDU is the international body for over 80 centre-right parties, such as the US Republicans and the British and Canadian conservative parties. ${ }^{52}$ It has regular meetings at which member parties can exchange ideas and election-winning techniques and strategies. Australian Prime Minister John Howard was elected IDU chairman in 2002 and served in this capacity for 12 years, making the introduction of the APPDP by his government extremely timely.

On the other side of politics, the disclosure returns revealed that the AusAID funds were being used to pay part of a senior Labor Party official's salary. ${ }^{53}$ The ensuing outcry resulted in an announcement that the program had been scrapped, as part of the Abbott Government's cuts to the aid budget. ${ }^{54}$ However, interestingly, 'negotiations' led to the program being reinstated, back in the Finance portfolio. It was difficult to locate in the 2015-16 Portfolio Budget Statement, as there was no spending line corresponding to the program and only a reference that key deliverables relating to parliamentary entitlements included 'management and support of the approved Political Party Programmes

51 Australian National Audit Office (ANAO) (2009) The Administration of Grants under the Australian Political Parties for Democracy Program, ANAO Report No. 18, Canberra: ANAO, available at: anao.gov.au/Publications/Audit-Reports/2008-2009/The-Administration-of-Grantsunder-the-Australian-Political-Parties-for-Democracy-Program.

52 The IDU calls itself 'The Freedom International' in an implied contrast with the Socialist International. See idu.org.

53 Pamela Williams (2013) 'How AusAID Pays for Labor Official's Salary', Australian Financial Review, 15 November; Michael Smith (2014) Australian Political Parties for Democracy Program: Ripe for Rorting', News.com, 5 February.

54 Noel Towell (2014) 'Political Parties Stripped of Millions in Junket Cash', Sydney Morning Herald, 14 February. 
within the entitlement framework' (p. 56). So although the program is a 'key deliverable', expenditure on it is buried under 'administered expenses' and, according to a Department of Finance spokeswoman, '[d]etails about the expenditure under the current APPDP deeds are not available publicly'. ${ }^{55}$

Subsequently, The Australian newspaper gained APPDP program plans and acquittals through a freedom of information (FOI) request, finding that the Labor and Liberal parties were still spending the money on maintaining relations with overseas counterparts in the developed world and with the Socialist International and IDU, respectively. The Labor Party spent only about 43 per cent of its funding in developing countries while the Liberal Party did not even specify the proportion spent on this purpose..$^{56}$

Paradoxically, one of the aims of the program is to 'encourage representative, accountable, inclusive and transparent democratic political parties', making the secrecy surrounding its funding and the need to use FOI to find out anything about it particularly reprehensible. Only The Greens admit to its existence on their Global Greens website and outline how it has been used. Clearly, it is not in the interests of the cartel parties to draw attention to misuse of this funding source or indeed to its existence at all, and this contributes to the lack of accountability. Occasional publicity about the program seems entirely accidental, as when an undercover conservative campaign group in the United States caught on camera Young Labor members trying to remove Donald Trump campaign signs. They were recorded boasting about Australian taxpayer funds paying for their work on the Bernie Sanders campaign for the Democratic presidential nomination..$^{57}$

55 An inquiry to the officer in the Department of Finance managing the program was passed to the Department's Media Centre, which responded on 7 December 2015 that: 'the budgeted expenses for APPDP fall under administered expenses. It is incorporated in the ordinary annual services (Appropriation Bill No. 1) budget. Details about the expenditure under the current APPDP deeds are not available publicly.'

56 Sean Parnell (2016) 'Labor Envoys Campaigned for Sanders', The Australian, 15 April, p. 8. 57 Tom McIlroy (2016), 'ALP Operatives on Taxpayer-Funded US Trip Caught up in Hidden Camera Campaign Sting', Sydney Morning Herald, 28 February, available at: smh.com.au/federalpolitics/political-news/alp-operatives-on-taxpayerfunded-us-trip-caught-up-in-hidden-cameracampaign-sting-20160227-gn5chk.html. 
This secrecy can be compared with the relative transparency of an overseas equivalent, despite some similar issues. In Germany, the Federal Ministry for Economic Cooperation and Development has a webpage about the funding of the German political foundations. ${ }^{58}$ There are six of them, and government funding is divided between them in proportion to their affiliated party's representation in the Bundestag. Funded to provide democracy assistance domestically as well as overseas, including promotion of civil society (and trade unions, in the case of the Friedrich Ebert Foundation), they are credited with an important role in the transitions to democracy in Spain and Portugal and later in Chile. ${ }^{59}$

In the 1980s there were scandals over the German foundation funds being used as a source of domestic party finance and there was a Constitutional Court challenge by the Greens. As a result, the system was strengthened and the Greens were incorporated into it. Theoretically, the foundations are not allowed to pass funding on to their affiliated party. In practice, relations between parties and foundations have been labelled 'symbiotic', and both Transparency International and Germany's Taxpayers' Alliance have continued to press for regular governmental reports on the funding of political foundations. A renewed suit challenging the foundations' 'hidden party financing' was filed in 2012 by the small Ecological-Democratic Party (ÖDP), but was rejected in August 2015 by the Constitutional Court. ${ }^{60}$

\section{Regulating the private funding of party politics}

Moving on from secretive public funding to the regulation of private funding of political parties: broadly speaking, the regulation of political finance in Australia was extremely laissez faire for about 30 years from 1980, when previous campaign expenditure limits were dropped at the federal level. Public funding was introduced in

\footnotetext{
58 Federal Ministry for Economic Cooperation and Development (2010-16) Bilateral Development Cooperation: Players-Political Foundations, Bonn: Ministry for Economic Cooperation and Development, available at: bmz.de/en/what_we_do/approaches/bilateral_ development_cooperation/players/political_foundations/index.html.

59 Michael Pinto-Duschinsky (1991) 'Foreign Political Aid: The German Political Foundations and their US Counterparts', International Affairs 67(1): 3363; Ann L. Phillips (1999) 'Exporting Democracy: German Political Foundations in Central-East Europe', Democratization 6(2): 70-98. 60 Information kindly provided by Rainer Eisfeld.
} 
this period in most jurisdictions but did not (as intended) lessen the reliance of the major political parties on private donations to meet rising campaign costs. There were no controls on the source or size of donations and few limits to expenditure or restrictions on electronic advertising (apart from a three-day ban immediately before and on election day). The only regulatory requirements were for disclosure of donations, but these were very lax, with many loopholes and with scheduled disclosure usually coming long after the electoral event for which the donations were made. A notable example of this was the disclosure some 16 months after the 2004 federal election of a million-dollar campaign donation made to the Liberal Party by Lord Ashcroft, a citizen of the United Kingdom and Belize. This donation also highlighted the lack of restrictions concerning foreign donations despite this being a standard item in international guidelines relating to political finance regulation. ${ }^{61}$

While the level of disclosure thresholds and the timing/frequency of reporting have been the subjects of reform efforts in Australia, other important issues are the types of activities covered (or not) by disclosure provisions. As discussed in the concluding chapter of this volume, there is a highly lucrative source of revenue for the major parties in selling 'access' to senior party figures through charging for places at dinners and receptions that they attend. This source of revenue can be legally hidden; if it involves purchasing access and influence for companies, it can be classified as a legitimate 'business expense' rather than as a donation. ${ }^{62}$ Apart from the electoral integrity principles involved, which led the former Queensland Labor Premier Anna Bligh to forbid her ministers attending such events, the selling of access also offends against equality principles by giving those with corporate money at their disposal privileged access to ministers. At the same time, reliance on external sources of funding potentially diminishes the role of party members.

A series of scandals at State and local government levels concerning political donations by property developers led to a tightening of political finance regulation in NSW and Queensland, starting with

61 See, for example, Elin Falguera, Samuel Johns and Magnus Ohman (eds) (2014) Funding of Political Parties and Election Campaigns: A Handbook on Political Finance, Stockholm: International IDEA, available at: idea.int/publications/funding-of-political-parties-and-electioncampaigns/.

62 Sawer et al., Australia, p. 141. 
a ban on developer donations in NSW in 2009 and leading on to the introduction of caps on donations and expenditure in both States. A new Coalition government in NSW then attempted to go further and copy the Canadian example of banning corporate or union donations and restricting the right to make political donations to individuals on the electoral roll. This legislation was extremely controversial because it prevented the payment of union affiliation fees to the Labor Party, thus interfering with the party's internal structure, which had been in place for more than 100 years. It was subsequently disallowed by the High Court on the grounds that it was in breach of the freedom of political communication. ${ }^{63}$ The case illustrated how different democratic principles - including those of a level playing field, electoral integrity, freedom of political expression and freedom of association - may be jostling with each other and with partisan interests in electoral regulation.

Meanwhile, political finance reform at the federal level had stalled, despite commitments by the Rudd Government and by Senator John Faulkner as Special Minister of State. This was not only because of partisan opposition but also because of opposition from State Labor Party branches that had been successful in raising large business donations. Scandals concerning money and politics have been more difficult to keep on the front page at the federal level and less effective in promoting reform. While federalism has lived up to its reputation for nourishing policy experimentation at the subnational level, the 'enervation' at the federal level ${ }^{64}$ has ensured the continuation of loopholes in political finance regimes. For example, NSW property developers, who are prohibited from making political donations in that State, were able to make large donations to the federally registered Free Enterprise Foundation, which was then able to pass the money on to the NSW Liberal Party. The NSW Premier, frustrated with the way his relatively tight political finance regime was undermined by the lax federal system, called in 2015 for a national political finance regime to be put on the agenda of the Council of Australian Governments

63 Unions NSW $v$ New South Wales (2013), HCA 58 (18 December). The subsequent McCloy case and its implications for campaign finance regulation are discussed in Chapter 8.

64 Graeme Orr (2016) 'Party Finance Law in Australia: Innovation and Enervation', Election Law Journal 15(1): 58-70. 
(COAG) ${ }^{65}$ Matters came to a head in 2016 when the NSW Electoral Commission withheld $\$ 4.4$ million in public funding from the Liberal Party on the grounds of inadequate disclosure of private funding channelled through the Free Enterprise Foundation. ${ }^{66}$

The trade-off for increased regulation of private donations is often increased public funding. Indeed, NSW has even looked at banning all private donations and having full public funding of election campaigns (one of the terms of reference for the inquiry set up by the NSW Premier in 2014). The ACT has introduced relatively strict regulation of expenditure, in effect from the beginning of 2016: $\$ 40,000$ per candidate, third party or associated entity in the election year. The ACT has also introduced the highest rate of public funding in Australia: \$8 per vote in 2016 for parties or a candidate gaining at least 4 per cent of the vote. Both major parties argued this higher rate of funding would help reduce their reliance on donations, but paradoxically at the same time removed the previous cap on such donations. ${ }^{67}$ As The Greens commented, '[t]he big parties are taking with one hand, and then taking with the other' ${ }^{6}{ }^{68}$

It is clear that lax regulation and recurrent scandals over both private and public funding have contributed to the low esteem in which Australian political parties are held. Transparency International's 2013 Global Corruption Barometer found that, in Australia, 58 per cent of respondents felt that political parties were corrupt or extremely corrupt. Political parties were seen as more corrupt than any other political institution except the media. ${ }^{69}$

65 Sean Nicholls (2015) 'Political Leaders Urged to Unite in Overhaul of Political Donations Law', Sydney Morning Herald, 28 July, available at: smh.com.au/nsw/mike-baird-to-takenational-donations-reform-to-coag-20150727-ggvks0.html.

66 Sarah Gerathy (2016) 'Liberal Party used "Charitable" Free Enterprise Foundation to Disguise Donations: NSW Electoral Commission', ABC News, 24 March, available at: abc.net.au/ news/2016-03-24/nsw-liberal-party-disguised-political-donations-free-enterprise/7272446.

67 For the changes to campaign finance laws in the ACT, see elections.act.gov.au/news/2015/ changes_to_act_legislative_assembly_campaign_finance_laws_commence_today_3_march_2015.

68 'Cap on Donations Removed by New ACT Laws', ABC News, 20 February 2015, available at: abc.net.au/news/2015-02-20/cap-on-political-donations-removed-by-new-act-laws/6153332.

69 Transparency International (2013) Global Corruption Barometer, Berlin: Transparency International, available at: transparency.org/gcb2013/country/?country=Australia. 


\section{Regulatory bodies}

Australian electoral management bodies have a well-deserved reputation for professionalism and partisan neutrality. However, this creates the paradox that these bodies are usually reluctant to take on the kind of regulatory functions that might mire them in partisan controversy, such as regulation of truth in political advertising or oversight of party preselections. For example, the Australian Electoral Commission (AEC) has stated it wants no role in internal party management matters, preferring that the party or the courts resolve internal conflicts. ${ }^{70}$ One recent exception has been the NSW Electoral Commission, which has strongly supported a recommendation that governance and accountability obligations be introduced for political parties and that the Electoral Commission be the regulator of these. ${ }^{71}$

In general, regulatory responsibility for political parties is divided between government departments and bodies with statutory independence, such as electoral commissions. Electoral commissions generally have responsibility for administering election funding of political parties and disclosure regimes relating to gifts and donations. They are also responsible for party registration and auditing compliance with statutory requirements and are, in turn, answerable to a minister and to legislative oversight bodies such as the JSCEM at the federal level. On the other hand, it will be a finance department, directly under the control of the government of the day, that will have responsibility for regulating other forms of party funding such as the incumbency benefits outlined above and, at the federal level, the funding of party think tanks and international activities. Public servants are required to be responsive to the government of the day, and the Opposition and minor parties benefiting from public resources will have little incentive to push too hard on accountability and transparency issues. The Australian regulatory regime governing access to public resources (other than those allocated by electoral

70 Australian Electoral Commission (AEC) (2005) Funding and Disclosure Report Election 2004, Canberra: AEC, pp. 40-1.

71 NSW Electoral Commission (2015) 'The Final Report of the Expert Panel: Political Donations and the Government's Response', Submission to the Joint Standing Committee on Electoral Matters, 16 October, p. 14. 
commissions) is perhaps at odds with international standards, such as those set out in the Venice Guidelines on Political Party Regulation, requiring equal treatment of parties contesting elections.

\section{Expanding regulatory reach: Candidate selection}

Periodic media attention to 'branch stacking' and other dubious practices within parties affecting their role in legislative recruitment has led to calls for electoral management bodies such as the AEC to supervise party preselection ballots. However, as we have seen, the AEC is reluctant to take on this regulatory function for fear of being embroiled in partisan controversy. ${ }^{72}$ The same reluctance would apply in Queensland, where Electoral Commission Queensland was given audit powers in 2002 in relation to preselection ballots. This occurred under changes to the Electoral Act, requiring, for the first time in Australia, that party constitutions contain provision for preselections 'satisfying the general principles of free and democratic elections'. It is notable that as of 2015 no other jurisdiction has followed this path of legislating for internal party democracy.

However, it seems that the political parties have successfully fended off any statutory interference with their internal organisational practices only to find themselves coming under the purview of the courts regarding the extent to which their own rules are followed. In 1999 a South Australian Labor parliamentarian successfully sued his party in the Supreme Court for failing to follow its own rules in relation to membership. This illustrated the extent to which Australian courts had departed from the old view concerning the 'private' nature of political parties and were prepared to enforce party rules. Nonetheless, there remain doubts over the extent to which courts should be involved in the internal affairs of political parties and whether this is the best way to ensure procedural fairness. ${ }^{73}$

The issue of judicial versus legislative regulation is further explored in this volume by Anika Gauja.

72 Joint Standing Committee on Electoral Matters (JSCEM) (2001) User Friendly, Not Abuser Friendly: Report of the Inquiry into the Integrity of the Electoral Roll, Canberra: Parliament of Australia, available at: aph.gov.au/Parliamentary_Business/Committees/House_of_ Representatives_Committees?url=em/elecroll/report.htm.

73 For an overview of cases from 1993 onwards in which courts have accepted jurisdiction over intraparty disputes, see Orr, The Law of Politics, Ch. 6. 
Apart from concerns over malpractice there are also concerns over how appropriate it is to have legislators effectively selected by a shrinking party membership that is not even seen to be particularly representative of party voters. This has led to various reform proposals for 'community preselections', giving members of the community a role in preselection, and The Nationals and the Labor Party have experimented with these. Yet these participatory reforms raise several important regulatory issues, including how such intraparty contests should be funded, the extent to which they should be subject to external oversight, as well as the rights of non-members to challenge party processes and decisions. ${ }^{74}$

Turning from the question of more open methods of candidate selection to more inclusive candidate selection, it is notable that candidate selection falls outside the protection of antidiscrimination legislation in Australia. ${ }^{75}$ Political parties are also exempt from statutory equal opportunity requirements of any kind, unlike in many comparable countries. For example, Ireland, a country from which Australia inherited a number of its political traditions, in 2012 opted to follow other European countries in legislating an electoral gender quota. Under the Irish legislation, political parties would lose 50 per cent of their public funding at the 2016 general election unless women (and men) made up at least 30 per cent of their candidates.

Australia has not followed suit in terms of legislation, although the Australian Labor Party did introduce an effective party quota in 1994. Labor's quota has led to a significant increase in the proportion of women in its parliamentary parties: by May 2015, women had become 43 per cent of Labor parliamentarians around Australia. This has not led, however, to the phenomenon of 'contagion of women candidates' identified in Europe, when adoption of quotas by one party leads to other parties significantly increasing their number of women candidates, whether by quotas or otherwise. ${ }^{76}$ On the contrary,

74 Graeme Orr (2011) 'Party Primaries for Candidate Selection? Right Question, Wrong Answer', University of New South Wales Law Journal 34(3): 964-83.

75 See Graeme Orr (2011) 'Legal Conceptions of Political Parties through the Lens of AntiDiscrimination Law', in Joo-Cheong Tham, Brian Costar and Graeme Orr (eds) Electoral Democracy: Australian Prospects, Melbourne: Melbourne University Press.

76 Richard E. Matland and Donley T. Studlar (1996) 'The Contagion of Women Candidates in Single-Member District and Proportional Representation Electoral Systems: Canada and Norway', Journal of Politics 58(3): 707-33. 
the Liberal Party, for example, has had a falling number of women preselected for winnable federal seats. What follows is that parties of the right have relatively few women in their parliamentary parties on whom to draw for executive office.$^{77}$ In turn, this means that, generally, when governments change, so does the gender composition of cabinets, despite Australia's international commitments to achieving gender balance in public decision-making. The soft regulation deriving from these treaty commitments has so far failed to reach across the political spectrum, but is unlikely to be exchanged for hard regulation linking public funding to gender diversity of candidates.

These recent developments illustrate both the opportunities and the potential pitfalls for legislators, who, in adopting regulatory reforms, have to take into account the interests of their own parties, the limits posed by public opinion (for example, concerning the public funding of political parties or gender quotas) as well as the normative objectives sought through party regulation. As we have seen, these objectives include protection against bribery and corruption; support for healthy party competition; reduction in reliance on large private donors, or at least an increase in transparency; encouragement of internal democracy and fair and open processes; and promotion of more inclusive candidate selection. The overall goal has been to ensure that political parties are able to fulfil their democratic functions in a way that sustains public confidence in the political system and results in greater citizen engagement in politics. There is a gap, however, between what we seek from party regulation and what is actually achieved. This volume will investigate why this gap exists in the particular case of Australia, although the findings will have resonance elsewhere.

77 In September 2016, women constituted 42 per cent of Labor parliamentarians around Australia but only 23 per cent of Liberal parliamentarians. See 'Composition of Australian Parliaments by Party and Gender, as at 16 September 2016', Canberra: Australian Parliamentary Library, available at: www.aph.gov.au/About_Parliament/Parliamentary_ Departments/Parliamentary_Library/pubs/rp/rp1617/Quick_Guides/PartyGender. 


\section{Structure of the book}

As noted above, research has begun to be published on party regulation in Australia, particularly relating to campaign finance, but this is the first full-length book to deal with all aspects of party regulation. Chapter 1 has introduced comparative perspectives on the legal and constitutional recognition of political parties and their place in democracy. It covers debates on key issues around party regulation and recent developments in Australia, which illustrate some of the main areas of contention.

The second chapter, by Sarah John, introduces a case study of the failure of the Whitlam Government to achieve party registration in the 1970s. The case study is used to illustrate more general patterns in the progression from party recognition to party regulation and the partisan and other dynamics involved. Of particular interest are the kinds of recompense offered for increased levels of regulationnot only party labels on ballot papers but also tax benefits and public funding.

In the third chapter, Norm Kelly opens up the subject of the effects of party regulation on the party system, including the number and diversity of political parties and the opportunities they provide for political participation. He explores the world of the microparties and finds that many provide little opportunity for members to be involved in party activities and may actually discourage such participation.

Yvonne Murphy (Chapter 4) then introduces a topic that has generally been neglected: the question of the regulation of parliamentary party status and the access to resources brought by such status. She shows how the requirements for such status vary across Australia and how those unable to meet the requirements have to rely on negotiation with government. While microparties argue their need for additional resources to cover all portfolio areas, allocation depends on bargaining power rather than need.

Political finance scholarship has been particularly strong in Australia and the next two chapters provide major new contributions to this scholarship. Graeme Orr (Chapter 5) provides a case study of Queensland to illustrate the political dynamics of regulation in this area and to probe the relevance or otherwise of the cartel thesis. Jennifer 
Rayner (Chapter 6) questions whether campaign finance regulation can achieve one of its stated aims: the achievement of a level playing field for electoral competition. Her rich empirical evidence and two case studies, from NSW and Queensland, suggest that donation and spending caps may not achieve this aim, although there are other arguments to support them.

In Chapter 7, Anika Gauja grapples with the puzzle of why political parties have been able to defend their claim to 'autonomy' in relation to their internal organisation so successfully, particularly compared with other voluntary organisations in receipt of public funding. She finds that while the parties of government have had a vested interest in fending off regulation of their internal workings, courts have become more willing to require that principles of natural justice and democratic governance apply in intraparty decision-making.

The conclusion (Chapter 8) to the book summarises the evidence as to why the gap exists between international standards and Australian practice or between the regulatory treatment of political parties as privileged political actors and their failure to attract members or adhere to principles of democratic governance. It recommends that to close the gap between aspirations and achievement, reform of party regulation should be a more inclusive process, involving political actors beyond parties already in parliament. In the end, however, the democratic principles involved remain contested (for example, internal democracy versus effective party competition) and their implementation will always need further scrutiny. 
This text is taken from Party Rules?: Dilemmas of political party regulation in Australia, edited by Anika Gauja and Marian Sawer, published 2016 by ANU Press, The Australian National University,

Canberra, Australia. 